\title{
Simultaneous consumption of drugs and their neuropsychological implications
}

\author{
Hugo Sánchez Castillo3, 2, I, Rodrigo Iván Castañeda Garrido', Diana Berenice Paz Trejo 4, 2, I, \\ Daniel Soltero de la Rosa', Pavel Zárate González' \\ I Sociedad Iberoamericana de Neurociencia Aplicada, SINA Iberoamérica, Ciudad de México, México \\ 2 Laboratorio de Neuropsicofarmacología, Facultad de Psicología, Universidad Nacional Autónoma de México, México \\ 3 Departamento de Psicobiología y Neurociencias, Facultad de Psicología, Universidad Nacional Autónoma de México, México \\ ${ }^{4}$ Sistema de Universidad Abierta y a Distancia, Facultad de Psicología, Universidad Nacional Autónoma de México, México
}

RESUMEN

Introducción: el abuso de sustancias es un problema de salud pública, afecta a millones de personas en el mundo y puede definirse como una condición recurrente en la que la conducta es realizada para generar placer y reducir el malestar producido por la ausencia de la sustancia. El retiro de la sustancia provoca alteraciones cognitivas en la memoria y en las funciones ejecutivas. Estas últimas debido a la especial vulnerabilidad de la corteza prefrontal a los efectos de las drogas. El policonsumo, definido como la ingestión simultánea o en un corto periodo de tiempo de varias sustancias, ha sido poco explorado en comparación con otros tipos de adicción. Objetivo: evaluar los efectos del policonsumo en tres grupos de participantes policonsumidores de sustancias, con una batería de evaluación neuropsicológica. Método: participaron 36 policonsumidores de sustancias y 11 participantes no consumidores que integraron el grupo control (47 en total). Fueron divididos por el tipo de sustancia de abuso, evaluados con la batería estandarizada "Neuropsi Atención y Memoria" y comparados con el grupo control. Conclusión y discusión: se observaron afectaciones neuropsicológicas en la memoria verbal y en la evocación tanto verbal como visoespacial, así como en la actitud abstracta y la inhibición $(p<0.05)$. Se observaron también varias recaídas y constantes reingresos a centros de rehabilitación. Los hallazgos sugieren que este tipo de usuarios presenta afectaciones importantes en inhibición y actitud abstracta, mismas que podrían provocar poca adherencia al tratamiento, alteraciones en sus actividades cotidianas y frecuentes recaídas.

Palabras clave: adicción, corteza prefrontal, evaluación neuropsicológica, funciones ejecutivas, policonsumo de sustancias.
ABSTRACT

Introduction: drug abuse is a health problem that affects millions of people around the world. It could be defined as a concurrent condition in which the behavior has the goal of produce a pleasant sensation and reduce the discomfort produced by the interruption of the drug administration. The drug retirement produces cognitive alterations, particularly in memory and executive function. Those effects are due to the vulnerability of prefrontal cortex to the drug effects. Poly drug use is defined as the simultaneous intake, or separated in short time lapses, of several drugs. This kind of drug intake has been poorly studied in comparison to other addictions. Objective: to evaluate the effects of poly drug use in three groups of drug consumers evaluated with a neuropsychological battery. Method: thirty-six poly drug consumers were included and eleven non consumers integrated a control group (total sample: 47 subjects). Poly drug consumers were divided in three different groups depending on the kind of drugs consumed. All poly drug users were evaluated with the Neuropsychological battery "Neuropsi Atención y Memoria" and were compared against the performance of control group. Conclusion and discussion: neuropsychological affections were observed, particularly in verbal memory and evocation (both verbal and visuospatial) as well as in abstract attitude and inhibition $(p<0.05)$. We observed several relapses and readmissions in the rehabilitation center. The findings over inhibition and abstract attitude could explain the poor adhesion to treatment, alterations in everyday life and several relapses.

Keywords: addiction, prefrontal cortex, neuropsychological assessment, executive function, poly drug consume.

\section{Corresponding author:}

Hugo Sánchez Castillo, PhD. Laboratorio de Neuropsicofarmacología, cub. B001, 1.er piso del Edificio B, Facultad de Psicología, UNAM. Av. Universidad 3000, col. Copilco Universidad, Alcaldía de Coyoacán, C.P. 04510, Ciudad de México, México. Tel.: +52 55 56228222 ext 41354. Cel. +521 38766876. Correo electrónico: ajuscoman@gmail.com

Recibido: 3 de julio de 2018

Aceptado: 12 de octubre de 2018

doi: 10.28931/riiad.2018.2.01 


\section{INTRODUCTION}

Substance addiction can be defined as a condition in which a behavior is focus on producing pleasure and diminish painful stimuli; is presented in a pattern defined by a recurrent failure in the control of the behavior despite knowing its harmful consequences. This condition is maintained due to the presence of positive reinforcement mechanisms aimed at the reexperimentation of the pleasurable sensations produced by the substance and the negative reinforcement due to the need to repeat the consumption and avoid the unpleasant sensations caused by the abstinence (Goodman, 2008; United Nations Office on Drugs and Crime, 2015). Right now, it is a global public health problem with an estimated prevalence of 27 million people, of which only one in six has access to treatment (United Nations Office on Drugs and Crime, 2015).

The combination of positive and negative reinforcement in the addictive process, leads the user to a trigger cycle divided into three stages. 1) The intoxication stage, where a dopaminergic release occurs in the striatum associated with the subjective descriptors of the substance, 2) the withdrawal stage characterized by hypofunctioning in the dopaminergic pathways due to the decrease in the dopaminergic receptors of subtype D2 and by a marked hypofunctioning of areas such as the dorsolateral prefrontal cortex (DLPFC), the orbitofrontal cortex (OFC) and the anterior cingulate cortex (aCC), these alterations cause anhedonia and executive deficits, 3) finally, the stage of concern or anticipation, is determined by the increase in the search for the substance and the increase in stress that activates the circuits involved in the processing of the reward, the attentional pathways and the mnemonic pathways related to the consumption memories, causing hypersensitivity to contextual clues (Koob \& Volkow, 2009).

Currently, it is known that the prefrontal cortex (PFC) is vulnerable to show the effects of substance abuse (Pedrero-Pérez, Rojo-Mota, Ruiz-Sánchez de León, Llanero-Luque, \& Puerta-Gárcía, 2011; Ruiz Sánchez de León et al., 2011; Sullivan, 2007; Verdejo, Orozco-Giménez, Sánchez-Jofré, Aguilar, \& Pérez-García, 2004). Alterations in of gray matter volume, hypofunctioning in the DLPFC and executive disruptions such as planning, mental flexibility, self-monitoring and other functions of the frontal lobe as inhibitory control (Goldstein et al., 2004). Based on these findings, it has been argued that executive functions (EF) play an important role in the initiation and maintenance of addiction (Hadjiefthyvoulou, Fisk, Montgomery, \& Bridges, 2012; Koob \& Volkow, 2009; Noël et al., 2001).

In addition to the kind and frequency, the consumption of substances may occurs in a pattern called poly drug use (Brière, Fallu, Descheneaux, \& Jasonz, 2011) and although there are few data on this, some research shows that the order and the combination of consumption determine a large part of the affectations (Schensul, Convey, \& Burkholder, 2005). For example, alterations in memory, in emotional processing and in executive functions have been found in poly drug users, the EF are expressed in a deficient cognitive and behavioral control mechanism that lasts up to one year after abstinence (Fernández-Serrano, Pérez-Garcia, \& Verdejo-García, 2011).

Several studies has also used molecular, neuropsychological and neuroimaging techniques to demonstrate some types of alterations in poly drug users; for example, positron emission tomography scans have shown negative correlations between performance in emotional processing tests and a hypofunction in the aCC that correlates in turn with executive alterations and functional decrease in the DLPFC, superior frontal girus and the lower parietal cortex (Moreno-López et al., 2012). Goldstein \& Volkow (2002) reported that the OFC, the aCC and their limbic connections show significant activation in stages of intoxication and compulsive search, while the same areas decrease their activity when the patient is under the abstinence syndrome.

It is also known, from studies that indicate alterations in neural circuits responsible for processes such as reward, motivation, memory, reactivity to stress, executive functioning and inhibitory control, that different types and stages of addiction induce neuroadaptive changes causing the passage of an impulsive action to a compulsive one (Koob \& Volkow, 2009).

Other researchers have used neuropsychological assessment and executive functioning inventories to identify alterations in planning, behavioral self-monitoring, inhibitory control and mental flexibility (Noël et al., 2001), from which it is concluded that patients experience this type of deficits in their daily life (Hadjiefthyvolou et al., 2012). Other authors have correlated similar data with emotional processing and have described alterations in the coding of contextual clues that act as a trigger to restart consumption (Brody et al., 2007; Goldstein \& Volkow, 2002; Jasinska, Stein, Kaiser, Naumer, \& Yalachkov, 2014; Moreno-López et al., 2012; Villalba \& VerdejoGarcía, 2012; Yalachkov, Kaiser, \& Naumer, 2009).

With respect to the withdrawal stage, alterations in the functioning of structures such as the DLPFC, the aCC and the OFC have been reported, which has led to the conclusion that they are the neuroanatomical substrate of the problems of inhibitory control and impulsivity, as well as a possible cause of frequent relapses (Koob \& Volkow, 2009). In relation to the OFC, negative correlations have been reported between the volume of gray matter and a 
shorter delay of reward, a distinctive feature in addictive disorders (Bjork, Hommer, Grant, \& Danube, 2004).

To the deficits described paragraphs above, we must add the vulnerability of the PFC in adolescence, considered as a critical period where the PFC still in development. This is of the utmost importance since it is now known that prefrontal areas are especially vulnerable to substances use and that the period of onset of consumption occurs at an earlier age (Brière et al., 2011; Klingberg, Vaidya, Gabrieli, Moseley, \& Hedehus, 1999).

Until today, the research supports a disrupted neurocircuit in the addictive process that involves different regions of the PFC, positioning it as a key area for the maintenance of addictive processes. Summarizing, the cognitive and emotional processing deficits that cause the overvaluation of the substance consumed, the devaluation of other reinforcing stimuli, and the hypersensitivity to contextual clues, trigger the memory and the need to restart consumption (Goldstein \& Volkow, 2002).

In Mexico there is no much information about the poly drug use, their implications and if this particular addiction is the same as the single drug addiction. Even why the users mix different kind of drugs.

The main goal of the present study was to evaluate the cognitive processes of voluntary poly drug users with a neuropsychological battery, this analysis focused mainly on cognitive function as well as their impact on the executive function.

\section{METHOD}

\section{Subjects}

47 Participants were included: 11 healthy non-drug users as control were recruited from an announcement and 36 poly drug users selected from an addiction rehabilitation center in Mexico City (Celia Meneses Center, Unidad Xochimilco, CDMX), the poly drug users met the diagnostic classification for the substance use disorder according to the fifth version of the Diagnostic and Statistical Manual of Mental Disorders (DSM V).

The inclusion criteria were that the participant were in the rehabilitation center, for two weeks at least; being without drug intake during the entire experiment; that does not have any other mental illness or neurological damage; that fulfilled with the diagnosis criteria for the drug addiction accord to the fifth version of the DSM V. Regarding the exclusion criteria, it was taken into account that the participants did not present any type of psychiatric or neurological disorder not related to alcohol intake (with exception of the Korsakoff Syndrome) and that neither of them was under withdrawal syndrome or under medical prescription (psychotropics) at the time the study started. To corroborate both points, we counted with the participation of the psychiatrist of the rehabilitation center.

\section{Instruments}

The neuropsychological battery "Neuropsi Atención y Memoria" (Neuropsy Attention and Memory) was used. This battery has been adapted and standardized for the Mexican population and is sensitive to the scholarship and age. Consists in tests that evaluate the functions of attention, memory and executive functions (Ardila, Ostrosky-Solís, Roselly, \& Gomez, 2000; Gómez-Pérez \& Ostrosky-Solís, 2006; Ostrosky-Solís, Ardila, \& Rosselli, 1999). Also, a semi-structured interview was used to learn about consumption habits.

\section{Procedure}

The participants of the experimental groups were selected by discretional method. In recruitment, subjects were informed that their participation would be anonymous, strictly voluntary and that they could withdraw from the study any time they wished. Those who agreed to participate were instructed to sign an informed consent letter. All the studies were approved by the ethic committee of the Cecilia Meneses Rehabilitation Center.

After that, a brief interview was conducted with the aim of knowing drug use habits (time of consumption, type of substances, period of abstinence, number of relapses, etc.). Once this information was collected, the battery application session was carried out with an approximate duration of one hour. The collection of all the data was made in approximately one month.

Participants were divided in control group and three different groups according to the type of preferred substance consumed: 1.- Stimulant drugs, cocaine, crack (E); 2.- Depressant drugs, alcohol, barbiturates, benzodiazepines, marijuana (D); 3.- Consumers of both kinds of substances $(E+D)$ and 4.- Control group (C) of non-consuming participants for which a maximum recreational alcohol consumption of two occasions per month was accepted. However, the number of cigarettes consumed was not taken as part of the exclusion criteria. Every group was defined following the criteria proposed by Font-Mayolas et al., (2013), however this criteria was made with European population (Spain).

Control group participants were selected by the snowball method, they were interviewed at the beginning in order to rule out the use of any drug not allowed to enter the research. Finally, those who met the inclusion criteria followed the same procedure as the poly drug consumer groups. 


\section{Statistical Analyses}

The SPSS software Version 25 (IBM, USA) was used, after confirming the homogeneity of the data with the Shapiro-Wilk method, One Way ANOVA was used having as a factor the group to which the participants belonged and as variables the score obtained when averaging the tests corresponding to the three cognitive functions that were evaluated: attention, memory and executive functions. The Tukey test was used as post hoc for all the comparisons, the data were considered significant with $p<.05$. In order to obtain a more specific analysis of cognitive functions, statistical analyzes were applied to the subscales that make up the battery. When the data did not have a normal distribution (verified with the shapiro-wilk method), the Kruskal-Wallis test with an asymptotic level of .05 was used.

\section{RESULTS}

Tables 1 and 2 show the sociodemographic data and consumption habits respectively. It can be observed that the most used substances are cocaine and marijuana, the latter was also the one that began to be used at a younger age, however, there is a lot of variation in the ages of onset of consumption of the substances among all the groups. There were no statistical differences among all groups $(p<.05)$.

Table 1

Sociodemographic characteristics of the sample

\begin{tabular}{|c|c|c|c|c|}
\hline \multirow[t]{2}{*}{ GROUP } & \multirow[t]{2}{*}{$n$} & \multicolumn{3}{|c|}{ DEMOGRAPHIC VARIABLE } \\
\hline & & & Mean & $\begin{array}{l}\text { Est. } \\
\text { Dev. }\end{array}$ \\
\hline \multirow[t]{2}{*}{ Depressor (D) } & 20 & Age & 35.5 & 12.07 \\
\hline & & Scholarship & 11.25 & 3.04 \\
\hline \multirow[t]{2}{*}{ Stimulant (E) } & 7 & Age & 26.0 & 2.44 \\
\hline & & Scholarship & 10.5 & 1.29 \\
\hline \multirow{2}{*}{$\begin{array}{c}\text { Stimulant + } \\
\text { Depressor } \\
(E+D)\end{array}$} & 9 & Age & 29.3 & 8.61 \\
\hline & & Scholarship & 11.4 & 2.06 \\
\hline \multirow[t]{2}{*}{ Control (C) } & 11 & Age & 23.6 & 5.35 \\
\hline & & Scholarship & 12.1 & 2.22 \\
\hline
\end{tabular}

This table show the different groups in which the participants were divided, the size of the sample, the age and years of scholarship. All data are reported with the means and standard deviation.
It was also found that both group $\mathrm{D}$ and $\mathrm{E}$ have maintained a period of abstinence of almost two years, while the group $E+D$ could only be without consuming the substances for a year; In relation to this data, it can be observed that, on average, groups $D$ and $E$ have entered rehabilitation twice and group $E+D$ three, this can be an indicator of the severity of the addiction and the additional difficulties that the participants of the $E+D$ group to maintain abstinence.

Table 3 presents the average of the natural score of the subscales as well the standardized score obtained in each of them. All those data were analyzed with the Kruskal-Wallis test.

The intergroup analysis by subtest confirms significant differences in several domains, mainly in the evocation and in the executive functions. In the case of the questions that evaluate time perception, space and person, significant differences are observed between the control group and $E+D$ group $\left(x^{2}{ }_{[3,47]}=9,007, p<.05\right)$.

There are important differences in the performance of the groups in the tests that evaluate the different types of memory. In the spontaneous memory curve subtest there are differences between the experimental groups and the control with respect to the total elements retained, in this subtest the group $E+D$ was the one that obtained the lowest performance $\left(x^{2}[3,47]=13.303, p<.05\right)$.

The evocation between the participants of this research with 7 subscales was examined, of which only 5 showed significant differences: 1 ) In the spontaneous verbal memory there was a significantly lower performance of the $E$ $+D$ group with respect to the control group $\left(\mathrm{x}^{2}{ }_{[3,47]}=\right.$ $8.876, p<.01 ; 2)$, in the verbal memory test for cues are differences between the $\mathrm{D}$ group versus the control group $\left.\left(x^{2}{ }_{[3,47]}=9.837, p<.05\right) ; 3\right)$, in the same way, when assessing verbal memory by recognizing the elements presented previously, significance was found between the control group versus D group, $\left(x^{2}{ }_{[3,47]}=8.577, p<.05\right)$; 4) the ability to evoke the items that make up a previously read story shows differences in the performance of the $E$ $+\mathrm{D}$ group versus the control group, and 5) Visuospatial evocation abilities, evaluated by asking the participant to remember the characteristics of the Rey-Osterrieth figure that he copied previously, were diminished in group $D$ with respect to group $C\left(x^{2}{ }_{[3,47]}=14,042, p<.01\right)$.

Regarding the executive functions, significant differences are observed in two tests, the first of them is Formation of Categories in which, the three experimental groups performed poorly compared to the control group $\left(x^{2}{ }_{[3,47]}=18,558, p<.001\right)$. There is also a lower performance between groups in the execution time in the Stroop Test, however, this result only reaches to be significant in group $\mathrm{D}$ when compared with the control group $\left(x^{2}[3,47]=10,218, p<.05\right)$.

REVISTA INTERNACIONAL DE INVESTIGACIÓN EN ADICCIONES 2018.4(2).1-9 
Table 2

Habits of consumption of the participants

\begin{tabular}{|c|c|c|c|c|c|c|c|}
\hline Group (n) & $\begin{array}{c}\text { Abstinence } \\
\text { (months) }\end{array}$ & $\begin{array}{l}\text { Admission / } \\
\text { readmission }\end{array}$ & Drug & $\mathrm{n}$ & $\begin{array}{c}\text { Age of } \\
\text { beginning of } \\
\text { consumption }\end{array}$ & $\begin{array}{c}\text { Years of } \\
\text { consumption }\end{array}$ & $\begin{array}{c}\text { Days of } \\
\text { consumption } \\
\text { per week }\end{array}$ \\
\hline \multirow[t]{2}{*}{ Depressor (20) } & 22 & 2 & Alcohol & 19 & 18.5 & 17.6 & 3.5 \\
\hline & & & THC & 5 & 16.2 & 8.6 & 5 \\
\hline \multirow[t]{2}{*}{ Stimulant (7) } & 23 & 2 & Cocaine & 4 & 19 & 5.5 & 7 \\
\hline & & & Crack & 3 & 18.3 & 7.6 & 3 \\
\hline \multirow[t]{4}{*}{$\begin{array}{c}\text { Stimulant + } \\
\text { Depressor (9) }\end{array}$} & 12 & 3 & Alcohol & 8 & 18.1 & 12 & 5 \\
\hline & & & THC & 3 & 18.6 & 12.3 & 3 \\
\hline & & & Cocaine & 8 & 19.2 & 11.2 & 3.6 \\
\hline & & & Crack & 2 & 17.5 & 2 & 4.5 \\
\hline
\end{tabular}

The habits of substance use are shown. Note that not all participants consumed all the drugs. The type of substance of abuse is presented together with the total number of volunteers who consume it, as well as the age of onset, years of ingestion, days of use per week, maximum period of abstinence and total income to a center of rehabilitation.

Table 3

Natural scores and standardized scores (SS) by group for each subtest of the NEUROPSI

\begin{tabular}{|c|c|c|c|c|c|c|c|c|}
\hline Subtest & $\begin{array}{c}\text { Score } \\
\text { Group } \\
\text { D }\end{array}$ & $\begin{array}{c}\text { SS } \\
\text { Group } \\
\text { D }\end{array}$ & $\begin{array}{c}\text { Score } \\
\text { Group } \\
\text { E }\end{array}$ & $\begin{array}{c}\text { SS } \\
\text { Group } \\
\text { E }\end{array}$ & $\begin{array}{c}\text { Score } \\
\text { Group } \\
E+D\end{array}$ & $\begin{array}{c}\text { SS } \\
\text { Group } \\
E+D\end{array}$ & $\begin{array}{c}\text { Score } \\
\text { Group } \\
\text { C }\end{array}$ & $\begin{array}{c}\text { SC } \\
\text { Group. } \\
\text { C }\end{array}$ \\
\hline & \multicolumn{8}{|c|}{ Orientation } \\
\hline \multirow[t]{2}{*}{ Total } & 6.5 & 23.2 & 6.5 & 22.2 & 5.8 & $11.9^{*}$ & 6.7 & 26.9 \\
\hline & \multicolumn{8}{|c|}{ Memory-Codification } \\
\hline \multirow[t]{2}{*}{ Memory curve } & 6.5 & $19.9^{*}$ & 6 & $15.6^{\star}$ & 5.7 & $15.1^{\star}$ & 8 & 33.1 \\
\hline & \multicolumn{8}{|c|}{ Memory- Evocation } \\
\hline $\begin{array}{l}\text { Spontaneous verbal } \\
\text { memory }\end{array}$ & 6.3 & 21.1 & 5.2 & 11.2 & 6.5 & $18.1^{\star}$ & 8.3 & 30.2 \\
\hline $\begin{array}{l}\text { Verbal memory - } \\
\text { Clues }\end{array}$ & 5.6 & $18.4^{*}$ & 5.5 & 17.2 & 6.5 & 19.5 & 9.1 & 32 \\
\hline $\begin{array}{l}\text { Verbal memory - } \\
\text { recognition }\end{array}$ & 9.8 & $18.9^{*}$ & 8.5 & 12.2 & 11.3 & 24 & 11.6 & 29.6 \\
\hline $\begin{array}{l}\text { Logical memory - } \\
\text { Histories }\end{array}$ & 7.9 & 23.1 & 7.2 & 19.5 & 5.2 & $12.1^{*}$ & 9 & 28 \\
\hline \multirow[t]{2}{*}{ Rey Osterrieth Figure } & 15.1 & $17.7^{\star}$ & 11.2 & 13.2 & 16.3 & 20.8 & 23.9 & 33.7 \\
\hline & \multicolumn{8}{|c|}{ Executive Functions } \\
\hline $\begin{array}{l}\text { Formation of } \\
\text { categories }\end{array}$ & 9.6 & $17^{*}$ & 9.5 & $16^{*}$ & 10.2 & $18.3^{\star}$ & 16.9 & 35.9 \\
\hline $\begin{array}{l}\text { Stroop- Time } \\
\text { interference }\end{array}$ & 2.8 & $17.5^{\star}$ & 3 & 17.6 & 3.37 & 22.9 & 3.9 & 30.9 \\
\hline
\end{tabular}


About the total battery scores, significant differences were found between the groups regarding attention and memory $\left(F_{[4,346]}=3, p<.05\right)$, as well between attention and executive functions $\left(F_{[10,280]}=3, p<\right.$ .05). Post hoc comparisons showed significance in the total score of attention and memory performance between groups $\mathrm{C}$ and $\mathrm{E}+\mathrm{D}$ and in attention and executive functions between groups $\mathrm{C}$ and $\mathrm{D} ; \mathrm{C}$ and $\mathrm{E}+\mathrm{D}$. The differences between group scores vary widely as we can check the analysis by subtest (Figure 1).

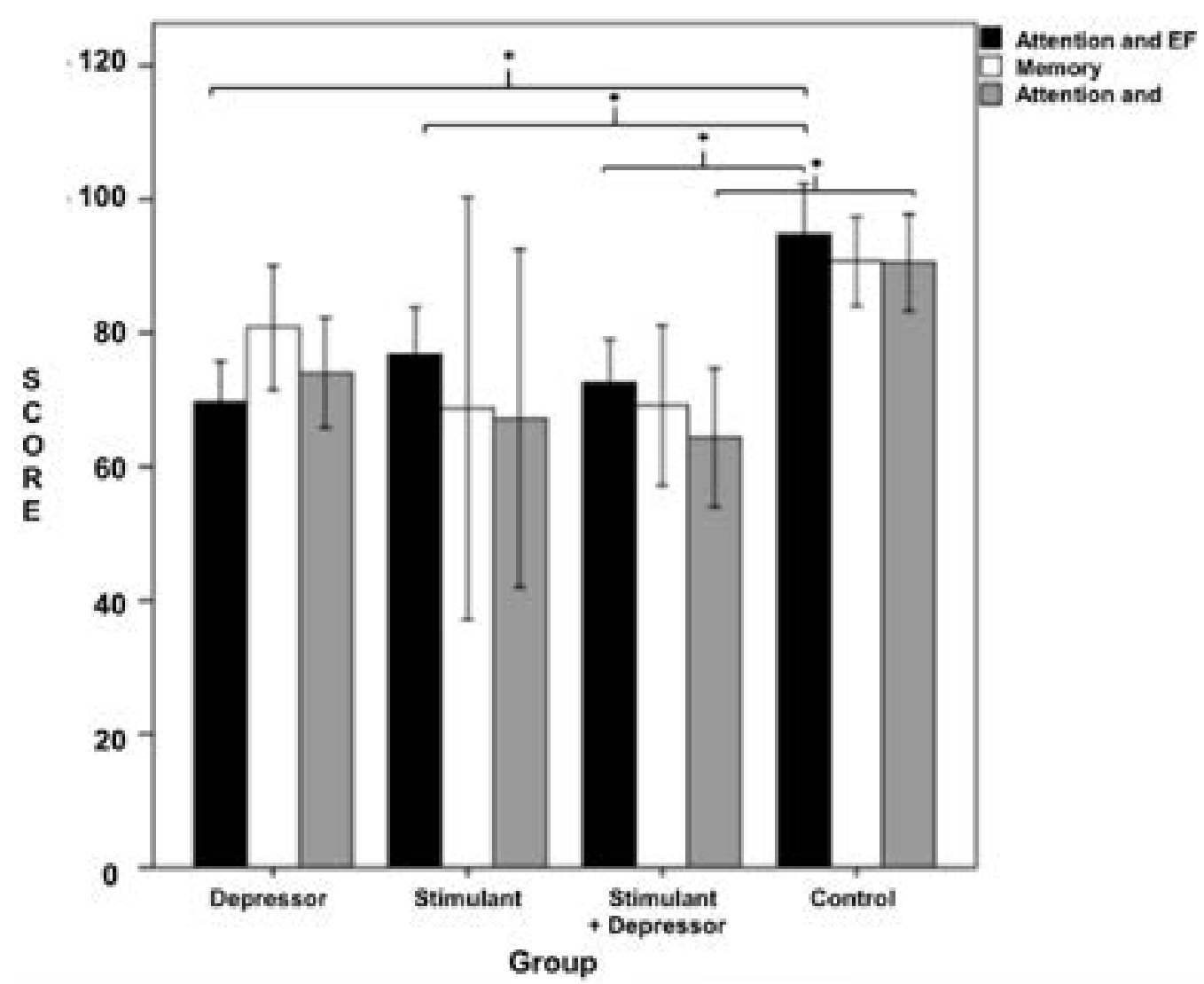

Figure 1. Significant differences were observed in the attention and memory domains between the control and $E+D$ group $(p<0.05)$. With respect to attention and executive functions, there are significant differences between the control and all other conditions $(p<0.05)$.

\section{DISCUSSION}

The aim of the present research was to evaluate the cognitive state of poly drug users with a battery of neuropsychological tests whose analysis focused particularly on cognitive functions and their involvement in the patient's daily performance. This is an important point of view due that, in general way, the rehabilitation processes is focused in the addiction without differentiate between the consumption of one single drug or many drugs (Pedrero-Pérez et al., 2011).

The results show important alterations in the EF in the three experimental groups, being these more evident in group $\mathrm{D}$. The analysis by subtest also showed alterations in other cognitive domains in D group, mainly in evocation, abstract attitude, and inhibition of automatic responses. This could be evidence that the poly consumers have different symptomatology depending on the drug or kind of drugs and that effect could evolve to a another pattern in the search of different drug experiences, however, it will bring it out differences in the undesired effects. Another interesting data of this research is that we observe that the group of Stimulant Plus Depressor $(E+D)$ does not have effects, that could be because the consumers could improve their deficiencies taking another kind of drugs, an sort of auto medication. 
As in other studies conducted with poly drug users (Goldstein et al., 2004; Koob \& Volkow, 2009; Noël et al., 2001), significant neuropsychological alterations were found in executive functions in all experimental groups with respect to the expected norm and the control group. However there is not much information about the Mexican population. These deficits cause substantial problems in user's performance in the cognitive field, where they faces difficulties to perform previously simple daily tasks and in the emotional field, where inhibiting impulses, relating with friends and family and interacting in key contexts requires more effort (Goldstein et al., 2004), and may again unleash consumer desires (Jasinska et al., 2014).

The poor performance of group D was observed in most of the tests related to executive functions, as has been reported in other trials where there is similar data mainly in adolescents (Oscar-Berman \& Marinkovié, 2007; Wollenweber et al., 2012). Another possible explanation in this regard focuses on the age of onset of consumption of the participants (18 years old average), age where the PFC is especially vulnerable to the consumption of substances (Brière et al., 2011; Sullivan, 2007). Finally, in the $\mathrm{D}$ group we can also observe that the alcohol intake in this particular group is more pronounced in comparison with the control and D + E group. This could be interpreted like the alcohol intake could be the trigger of the deficiencies, however none of the participants were diagnosed with Korsakoff syndrome, the standard deviation was great (12.07 years) and there was no statistical differences between ages.

On the other hand, the tests of retention of digits in regression and cubes in regression, in charge of evaluating working memory, detected visual differences in the performance of the groups that nevertheless do not reach to be significant, in spite of this, they resemble the conclusions of other similar works (Parada et al., 2012).

The subtest of category formation, which evaluates the ability to analyze and group semantic classifications, requires skills such as abstraction and mental flexibility, functions closely related to the DLPFC (Flores, 2001). The low performance obtained by the three experimental groups suggests that these skills are compromised, in agreement with previous studies that show similar data in this type of population (Bjork et al., 2004; Goldstein \& Volkow, 2002).

The analysis showed that the members of the $E+D$ group could only maintain the abstinence of consumption for twelve months on average in comparison with the twenty-two and twenty-three months that the members of the other groups $\mathrm{D}$ and $\mathrm{E}$ have reached, respectiveIy. In the same way, they had more income to rehabilitation centers compared to groups $\mathrm{D}$ and $\mathrm{E}$. This may be due to the low capacity of disengagement with the substance and the poor capacity of inhibition, functions that are closely related to mental flexibility, also involved in generating strategies of problem solving when the current ones are not adequate and in the change of the attentional focus from one stimulus to another (Villalba \& Verdejo-Garcia, 2012). This conclusion is derived from studies in which participants with cocaine consumption as a main drug and poly consumer have structural alterations such as gray matter reduction (Stuss \& Alexander, 2000) and hypofunctioning in DLPFC and OFC (Goldstein et al., 2004), which entails to alterations in cognitive flexibility as well as impulsiveness (Hadjiefthyvolou et al., 2012; Koob \& Volkow, 2009) finally triggering a poor performance in the global functioning of the EF that could explain the low capacity for abstinence and consequently the constant re-admissions.

The main limitations of the present investigation lies in the size of the sample, since it was not possible to include more patients of the characteristics required to be able to give greater validity and statistical power, one of the reasons of this phenomena is that the addictions in Mexico are associated with violence and drug cartels, causing that many poly drug users didn't use this rehabilitations centers or they not continue their treatment. Another limitation, derivative from the sample size, was not having control of some variables that could affect the results, particularly the years of consume between groups. However we like to add that the poly drug use is a condition in which the control of some variables is hard due the characteristic itself of the consume (for example the doses could not be the same in a single use vs polyconsume, the evolution of the polyconsume in terms of which kind of drugs the patients is adding to his consume, etc). For solving this problem we recommend a bigger sample size and include a most exhaustive control with the poly drug users. It is also recommended for future investigations to use more specific additional instruments that allow us to go deeper into the analysis of the alterations.

\section{Conclusion}

It has been possible to demonstrate that poly drug users present important neuropsychological deficits in the functions of abstract attitude and inhibition as well as short-term memory and both verbal and visuospatial evocation. These executive alterations are maintained and can cause relapses once the treatment is completed, which is why it is important to carry out this type of research and develop evaluation and rehabilitation strategies. The data obtained in the present investigation add to the few that have contributed information from poly drug users with a view to improving addiction rehabil- 
itation programs based on data provided by neuropsychology. Finally this report could help to future research to group the poly drug population due there is not much information about the patterns of poly drug use in Mexico, besides the National Survey of Addictions 2017 (Encuesta Nacional de Adicciones [ENA]) does not group the poly consume, only reports the incidence, kind of drug, prevalence, etc. (Villatoro et al., 2017).

\section{ACKNOWLEDGMENT}

Authors thanks "Celia Meneses" Rehabilitation Center for its collaboration and for allow access to its facilities.

\section{FUNDING}

Hugo Sánchez Castillo received support by Universidad Nacional Autónoma de México grants: DGAPA-PAPIIT IN306918 and DGAPA-PAPIME PE306318.

Opinions, findings and conclusions are from the authors and not necessarily from the sponsors mentioned above.

\section{CONFLICT OF INTEREST}

The authors have nothing to disclose.

\section{REFERENCES}

Ardila, A., Ostrosky-Solis, F., Rosselli, M., \& Gomez, C. (2000). AgeRelated Cognitive Decline During Normal Aging: The Complex Effect of Education. Archives of Clinical Neuropsychology, 15(6), 495-513. doi:10.1093/arclin/15.6.495

Bjork, J. M., Hommer, D. W., Grant, S. J., \& Danube, C. (2004). Impulsivity in abstinent alcohol-dependent patients: relation to control subjects and type 1-/type 2-like traits. Alcohol, 34(2-3), 133-150. doi:10.1016/j.alcohol.2004.06.012

Brière, F. N., Fallu, J.-S., Descheneaux, A., \& Janosz, M. (2011). Predictors and consequences of simultaneous alcohol and cannabis use in adolescents. Addictive Behaviors, 36(7), 785788. doi:10.1016/j.addbeh.2011.02.012

Brody, A. L., Mandelkern, M. A., Olmstead, R. E., Jou, J., Tiongson, E., Allen, V., ... Cohen, M. S. (2007). Neural Substrates of Resisting Craving During Cigarette Cue Exposure. Biological Psychiatry, 62(6), 642-651. doi:10.1016/j.biopsych.2006.10.026

Fernández-Serrano, M. J., Pérez-García, M., \& Verdejo-García, A. (2011). What are the specific vs. generalized effects of drugs of abuse on neuropsychological performance? Neuroscience \& Biobehavioral Reviews, 35(3), 377-406. doi:10.1016/j.neubiorev. 2010.04.008

Flores, J. (2001) Neuropsicología de lóbulos frontales. Barcelona: Crítica.

Font-Mayolas, S., Gras, M. E., Cebrián, N., Salamó, A., Planes, M., \& Sullman, M. J. M. (2013). Types of polydrug use among
Spanish adolescents. Addictive Behaviors, 38(3), 1605-1609. doi:10.1016/j.addbeh.2012.09.007

Goldstein, R. Z., Leskovjan, A. C., Hoff, A. L., Hitzemann, R., Bashan, F., Khalsa, S. S., ... Volkow, N. D. (2004). Severity of neuropsychological impairment in cocaine and alcohol addiction: association with metabolism in the prefrontal cortex. Neuropsychologia, 42(11), 1447-1458. doi:10.1016/j.neuropsychologia.2004.04.002

Goldstein, R. Z., \& Volkow, N. D. (2002). Drug Addiction and Its Underlying Neurobiological Basis: Neuroimaging Evidence for the Involvement of the Frontal Cortex. American Journal of Psychiatry, 159(10), 1642-1652. doi:10.1176/appi.ajp.159. 10.1642

Gómez-Pérez, E., \& Ostrosky-Solís, F. (2006). Attention and Memory Evaluation Across the Life Span: Heterogeneous Effects of Age and Education. Journal of Clinical and Experimental Neuropsychology, 28(4), 477-494. doi:10.1080/13803390590949296

Goodman, A. (2008). Neurobiology of addiction. Biochemical Pharmacology, 75(1), 266-322. doi:10.1016/j.bcp.2007.07.030

Hadjiefthyvoulou, F., Fisk, J. E., Montgomery, C., \& Bridges, N. (2012). Self-reports of Executive Dysfunction in Current Ecstasy/ Polydrug Users. Cognitive And Behavioral Neurology, 25(3), 128-138. doi:10.1097/wnn.0b013e318261459c

Jasinska, A. J., Stein, E. A., Kaiser, J., Naumer, M. J., \& Yalachkov, Y. (2014). Factors modulating neural reactivity to drug cues in addiction: A survey of human neuroimaging studies. Neuroscience \& Biobehavioral Reviews, 38, 1-16. doi:10.1016/j. neubiorev.2013.10.013

Klingberg, T., Vaidya, C. J., Gabrieli, J. D. E., Moseley, M. E., \& Hedehus, M. (1999). Myelination and organization of the frontal white matter in children. NeuroReport, 10(13), 2817-2821. doi:10.1097/00001756-199909090-00022

Koob, G. F., \& Volkow, N. D. (2009). Neurocircuitry of Addiction. Neuropsychopharmacology, 35(1), 217-238. doi:10.1038/npp. 2009.110

Moreno-López, L., Stamatakis, E. A., Fernández-Serrano, M. J., Gómez-Río, M., Rodríguez-Fernández, A., Pérez-García, M., \& Verdejo-García, A. (2012). Neural correlates of hot and cold executive functions in polysubstance addiction: Association between neuropsychological performance and resting brain metabolism as measured by positron emission tomography. Psychiatry Research: Neuroimaging, 203(2-3), 214-221. doi: 10.1016/j.pscychresns.2012.01.006

Noël, X., Van der Linden, M., Schmidt, N., Sferrazza, R., Hanak, C., Le Bon, O., ... Verbanck, P. (2001). Supervisory Attentional System in Nonamnesic Alcoholic Men. Archives of General Psychiatry, 58(12), 1152-1158. doi:10.1001/archpsyc.58.12.1152

Oscar-Berman, M., \& Marinkovié, K. (2007). Alcohol: Effects on Neurobehavioral Functions and the Brain. Neuropsychology Review, 17(3), 239-257. doi:10.1007/s11065-007-9038-6

Ostrosky-Solís, F., Ardila, A., \& Rosselli, M. (1999). NEUROPSI: A brief neuropsychological test battery in Spanish with norms by age and educational level. Journal of the International Neuropsychological Society, 5(05), 413-433. doi:10.1017/s1355617799555045 
Parada, M., Corral, M., Mota, N., Crego, A., Rodríguez Holguín, S., \& Cadaveira, F. (2012). Executive functioning and alcohol binge drinking in university students. Addictive Behaviors, 37(2), 167172. doi:10.1016/j.addbeh.2011.09.015

Pedrero-Pérez, E., Rojo-Mota, G., Ruíz-Sánchez de León, J., LlaneroLuque, M., \& Puerta-García, C. (2011) Rehabilitación cognitiva en el tratamiento de las adicciones. Revista de Neurología, 52(3), 163-72.

Ruiz-Sánchez de León, J., Pedrero-Pérez, E. J., Rojo-Mota, G., Llanero-Luque, M., \& Puerta-García, C. (2011) Propuesta de un protocolo para la evaluación neuropsicológica de las adicciones. Revista de Neurología, 53(8), 483-93.

Schensul, J. J., Convey, M., \& Burkholder, G. (2005). Challenges in measuring concurrency, agency and intentionality in polydrug research. Addictive Behaviors, 30(3), 571-574. doi: 10.1016/j. addbeh.2004.05.022

Stuss, D. T., \& Alexander, M. P. (2000). Executive functions and the frontal lobes: a conceptual view. Psychological Research, 63(34), 289-298. doi:10.1007/s004269900007

Sullivan, E. V. (2007). Alcohol and Drug Dependence: Brain Mechanisms and Behavioral Impact. Neuropsychology Review, 17(3), 235238. doi:10.1007/s11065-007-9039-5

United Nations Office on Drugs and Crime (2015). World Drug Report. Viena: United Nations.
Verdejo, A., Orozco-Giménez, C., Sánchez-Jofré, M., Aguilar, F., \& Pérez-García, M. (2004) Impacto de la gravedad del consumo de drogas sobre distintos componentes de la función ejecutiva. Revista de Neurología, 38(12), 1109-1116.

Villalba Ruiz, E., \& Verdejo-García, A. (2012). Procesamiento emocional, interocepción y funciones ejecutivas en policonsumidores de drogas en tratamiento. Trastornos Adictivos, 14(1), 10-20. doi: 10.1016/s1575-0973(12)70038-7

Villatoro, J. A., Resendiz, E., Mujica, A., Bretón, M., Cañas, V., Soto, I., \& Mendoza, L. (2017). Encuesta Nacional de Consumo de Drogas, Alcohol y Tabaco 2016-2017: Reporte de Drogas. Ciudad de México: Instituto Nacional de Psiquiatría Ramón de la Fuente Muñiz.

Wollenweber, F. A., Halfter, S., Brügmann, E., Weinberg, C., Cieslik, E. C., Müller, V. I., ... Eickhoff, S. B. (2012). Subtle cognitive deficits in severe alcohol addicts - Do they show a specific profile? Journal of Neuropsychology, 8(1), 147-153. doi:10.1111/jnp.12001

Yalachkov, Y., Kaiser, J., \& Naumer, M. J. (2009). Brain Regions Related to Tool Use and Action Knowledge Reflect Nicotine Dependence. Journal of Neuroscience, 29(15), 4922-4929. doi: 10.1523/jneurosci.4891-08.2009 